\title{
Production and characterization of biodiesel from trap grease
}

\author{
Ji-Yeon Park*, Jin-Suk Lee*,', Zhong-Ming Wang**, and Deog-Keun Kim* \\ *Korea Institute of Energy Research, 71-2, Jang-dong, Yuseong-gu, Daejeon 305-343, Korea \\ **Guangzhou Institute of Energy Conversion, No.2 Nengyuan Rd, Wushan, Tianhe, Guangzhou 510-640, China \\ (Received 21 July $2009 \cdot$ accepted 17 March 2010)
}

\begin{abstract}
The feasibility of the production of biodiesel from trap grease containing $51.5 \%$ free fatty acids (FFAs) was investigated. The esterification of FFAs by an acid catalyst followed by the transesterification of triglycerides by an alkali catalyst was examined. The esterification of trap grease by sulfuric acid as a homogeneous catalyst or by Amberlyst15 as a heterogeneous catalyst was optimized through a response surface methodology. After the two-step esterification of trap grease by sulfuric acid, the acid value decreased from $102.9 \mathrm{mg} \mathrm{KOH} / \mathrm{g}$ to $2.75 \mathrm{mg} \mathrm{KOH} / \mathrm{g}$. Through the transesterification by potassium hydroxide, fatty acid methyl ester (FAME) content reached $92.4 \%$. Following the esterification of trap grease by Amberlyst-15, the acid value decreased to $3.23 \mathrm{mg} \mathrm{KOH} / \mathrm{g}$. With the transesterification by potassium hydroxide, FAME content increased to $94.1 \%$. After the distillation of the produced biodiesel, FAME content increased again, to $97.6 \%$. The oxidation stability of the trap grease biodiesel was $0.17 \mathrm{~h}$, and its cold filter plugging point was $4{ }^{\circ} \mathrm{C}$. As the FAME content of the trap grease biodiesel satisfies the Korean Biodiesel Standard, the trap grease biodiesel seems to be applicable for use as an engine fuel after properties improvement.
\end{abstract}

Key words: Biodiesel, Trap Grease, Free Fatty Acids, Amberlyst-15, Response Surface Methodology

\section{INTRODUCTION}

Recently, there has been an increased interest in the use of biodiesel produced from triglycerides as an alternative fuel for diesel engines due both to the instability in the price of petroleum and to environmental concerns related to the air pollution generated by vehicles [1-3]. Biodiesel can be produced from diverse oils and fats, depending upon local agricultural policies, crop availability, and feedstock price [4-6]. Biodiesel is typically produced from edible oils, such as soybean oil, rapeseed oil, and palm oil. Recently, waste oils such as used frying oil, trap grease, soapstock, and acid oil have been considered as alternative feedstock for the production of biodiesel [3,7].

One of these waste oils, trap grease, is waste oil that is intercepted in the grease traps of restaurants to prevent it from entering the sewage system. It has free fatty acid (FFA) content ranging from $40 \%$ to $100 \%[8,9]$, and is plentiful in supply. For example, in Guangzhou, the third largest city in China, 20,000 tons of water-free trap grease is produced annually. As the Chinese government has banned the use of trap grease as animal feed, it is expected to become an attractive feedstock for biodiesel production [10].

The production of biodiesel from waste oils is one approach to lowering biodiesel production costs. However, waste oils have high FFA content. As FFAs form soap through an alkali catalyst, waste oils containing FFAs must be treated with an acid catalyst, or the FFAs must be removed prior to the transesterification process. FFAs react with alcohol under an acid catalyst, producing ester and water, while triglycerides react with alcohol under an alkali catalyst, producing ester and glycerol [11-14].

When waste oils were converted to biodiesel using catalysts, the

†To whom correspondence should be addressed.

E-mail: bmjslee@kier.re.kr
FAME content generated by an acid catalyst was lower than that generated by the sequential use of an acid catalyst and an alkali catalyst. In the process using an acid catalyst, the concentration of sulfuric acid was very high, at over $7.0 \mathrm{wt} \%$ [15].

The use of a homogeneous acid catalyst such as sulfuric acid for esterification causes difficulties in recovery after the reaction, and produces toxic wastewater. Solid acid catalysts have been studied as substitutes for sulfuric acid, and have the advantages of being easy to recover and reuse, as well as being compatible with environmental considerations. Of the solid acid catalysts, Amberlyst-15 is known as a catalyst with good properties in terms of its esterification efficiency [16-19].

In this study, biodiesel was produced from trap grease through a process involving esterification by sulfuric acid or Amberlyst-15, followed by transesterification by potassium hydroxide. Two acid catalysts were used to determine the optimal esterification condition for the production of biodiesel from trap grease.

\section{EXPERIMENTAL METHODS}

\section{Materials}

Trap grease, which had been collected from the grease traps of restaurants in Guangzhou, was kindly supplied by the Guangzhou Environmental Protection Agency in China, and its acid value was $102.9 \mathrm{mg} \mathrm{KOH} / \mathrm{g}$. The composition of the trap grease is summarized in Table 1. It was composed of 51.45\% FFAs, $0.67 \%$ monoglycerides, $9.40 \%$ diglycerides, $26.60 \%$ triglycerides, $4.40 \%$ glycerol, and $0.71 \%$ water. Of these components, FFAs, monoglycerides, diglycerides, triglycerides can be converted to biodiesel. Potassium hydroxide and ethanol (DC Chemical, Korea) were used for the analysis of the acid value. For esterification, methanol (Duksan Pure Chemical, Korea) and sulfuric acid (DC Chemical, Korea) as a homogeneous catalyst or Amberlyst-15 (Rohm \& Haas, France) 
Table 1. The composition of trap grease

\begin{tabular}{lr}
\hline \hline Composition & wt\% \\
\hline Free fatty acids & 51.45 \\
Monoglycerides & 0.67 \\
Diglycerides & 9.40 \\
Triglycerides & 26.60 \\
Glycerol & 4.40 \\
Water & 0.71 \\
Not measured & 6.77 \\
\hline
\end{tabular}

as a heterogeneous catalyst were used. Potassium hydroxide (Junsei Chemical, Japan) and methanol were used for the transesterification reaction. For gas chromatography analyses, n-heptane (J.T. Baker, USA), methyl heptadecanoate (Fluka, Switzerland), 1,2,4butanetriol (Supelco, USA), 1,2,3-tricaproylglycerol (Supelco, USA), and N-methyl-N-trimethylsilyl-trifluoroacetamide (Aldrich Chemical Co., USA) were used.

\section{Esterification and Transesterification of Trap Grease}

A previous study determined that the reaction temperature was $95^{\circ} \mathrm{C}$ for an acid catalyst esterification, and $80^{\circ} \mathrm{C}$ for an alkali catalyst transesterification [15]. The amount of catalyst and methanol varied according to the response surface methodology. For esterification, the trap grease, methanol, and catalyst were mixed. For transesterification, the pretreated trap grease was mixed with potassium hydroxide dissolved in methanol. All experiments were conducted in a round flask that was connected to a condenser to minimize the loss of methanol. After washing with distilled water and centrifuging at $15,000 \mathrm{rpm}$ for $15 \mathrm{~min}$, the properties of the biodiesel were analyzed. To improve the purity of the biodiesel, a simple distillation system was used. The vacuum was adjusted to $65 \mathrm{cmHg}$. The temperature was in the range of $160-220^{\circ} \mathrm{C}$, and the distillate was collected.

\section{Analyses}

The acid value was measured through the titration method (AOCS official method $\mathrm{Cd} 3 \mathrm{~d}-63$ ) using a $\mathrm{KOH}-\mathrm{ethanol}$ solution. The oxidation stability measurements were carried out with the model 743 Rancimat (Metrohm, Switzerland). Sample was analyzed under constant air flow of $10 \mathrm{~L} / \mathrm{h}$ at a heating block temperature of $110^{\circ} \mathrm{C}$. The temperature correction factor $\Delta \mathrm{T}$ was set to $1.5^{\circ} \mathrm{C}$. Cold filter plugging point (CFPP) measurements were carried out with the model FPP5Gs (ISL, France). Sample was cooled using the EN 116 method. At intervals of $1{ }^{\circ} \mathrm{C}$, a $200 \mathrm{mmH}_{2} \mathrm{O}$ vacuum was applied to draw up the sample into a pipette through a filter. The temperature at which the sample had ceased to flow through the filter within 60 seconds or had failed to return to the test jar was recorded as the CFPP.

The fatty acid methyl ester (FAME) content was analyzed through gas chromatography equipped with an auto-injector (Agilent 6890A, USA). The INNOWax (Agilent) column $(30 \mathrm{~mm} \times 0.32 \mathrm{~mm} \times 0.5$ $\mu \mathrm{m})$ was used for the analysis of FAME. The initial oven temperature was $50^{\circ} \mathrm{C}$ for $1 \mathrm{~min}$, and was increased to $200{ }^{\circ} \mathrm{C}$ at a rate of $15^{\circ} \mathrm{C} / \mathrm{min}$, maintained at $200^{\circ} \mathrm{C}$ for $9 \mathrm{~min}$, and then increased again to $250{ }^{\circ} \mathrm{C}$ at a rate of $2{ }^{\circ} \mathrm{C} / \mathrm{min}$ and held at that temperature for 2 min. Methyl heptadecanoate was used as the internal standard.

Total glycerin was determined by gas chromatography equipped with an on-column injector (Agilent 6890N, USA). The DB-5HT
(Agilent) column $(15 \mathrm{~m} \times 0.32 \mathrm{~mm} \times 0.1 \mu \mathrm{m})$ was used for the analytical work. The initial oven temperature was $50^{\circ} \mathrm{C}$ for $1 \mathrm{~min}$, which was increased to $180^{\circ} \mathrm{C}$ at a rate of $15^{\circ} \mathrm{C} / \mathrm{min}$, then to $230^{\circ} \mathrm{C}$ at a rate of $7{ }^{\circ} \mathrm{C} / \mathrm{min}$, and then to $370^{\circ} \mathrm{C}$ at a rate of $10^{\circ} \mathrm{C} / \mathrm{min}$, and then held at a temperature of $370^{\circ} \mathrm{C}$ for $10 \mathrm{~min} .1,2,4$-butanetriol and 1,2,3-tricaproylglycerol were used as the internal standards.

\section{RESULTS AND DISCUSSION}

\section{Esterification by Sulfuric Acid and Transesterification by Potassium Hydroxide}

In the esterification of trap grease by sulfuric acid, its acid value rapidly decreased within $1 \mathrm{~h}$, after which the rate of decrease was very slow (Fig. 1). Water produced during the esterification accel-

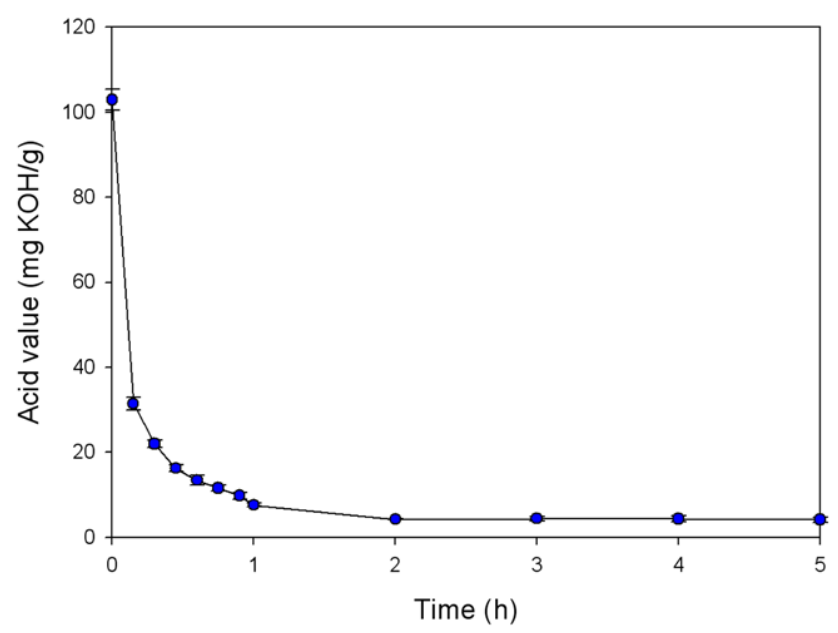

Fig. 1. Profile of the acid value in the esterification of trap grease by sulfuric acid $(9: 1$ molar ratio of methanol to oil and a $2 \mathrm{wt} \%$ catalyst at $\left.95^{\circ} \mathrm{C}\right)$.

Table 2. Experimental matrix of the central composite design for the first esterification by sulfuric acid

\begin{tabular}{rccccc}
\hline \hline Run & $\mathrm{x}$ & $\mathrm{y}$ & $\begin{array}{c}\text { MeOH to oil } \\
(\mathrm{X}, \text { molar } \\
\text { equivalents })\end{array}$ & $\begin{array}{c}\text { Sulfuric } \\
\text { acid to oil } \\
(\mathrm{Y}, \mathrm{wt} \%)\end{array}$ & $\begin{array}{c}\text { Conversion } \\
\text { of FFAs } \\
(\mathrm{Z}, \%)\end{array}$ \\
\hline 1 & -1 & -1 & 2 & 0.5 & 59.01 \\
2 & -1 & 0 & 2 & 1.5 & 69.86 \\
3 & -1 & 1 & 2 & 2.5 & 74.09 \\
4 & 0 & -1 & 6 & 0.5 & 84.23 \\
5 & 0 & 1 & 6 & 2.5 & 89.07 \\
6 & 1 & -1 & 10 & 0.5 & 85.58 \\
7 & 1 & 0 & 10 & 1.5 & 92.88 \\
8 & 1 & 1 & 10 & 2.5 & 90.44 \\
9 & -1.414 & 0 & 0.344 & 1.5 & 14.06 \\
10 & -1.414 & 0 & 11.666 & 1.5 & 90.80 \\
11 & 0 & -1.414 & 6 & 0.1 & 60.72 \\
12 & 0 & 1.414 & 6 & 2.9 & 89.88 \\
13 & 0 & 0 & 6 & 1.5 & 86.86 \\
14 & 0 & 0 & 6 & 1.5 & 86.72 \\
15 & 0 & 0 & 6 & 1.5 & 86.34 \\
\hline
\end{tabular}

$\mathrm{X}=4 \mathrm{x}+6 ; \mathrm{Y}=\mathrm{y}+1.5$ 
erated the inverse reaction towards the reactant and diluted the concentration of sulfuric acid in the reactant [20]. Therefore, a twostep esterification reaction was tested, in which the original methanol and catalyst were replaced with fresh methanol and catalyst after $1 \mathrm{~h}$. Through the replacement of methanol and catalyst, the produced water was removed.

Regression analysis and analysis of variance were performed using the SPSS software package (version 12.0). In the central composite design for the first esterification (Table 2), the relation between conversion (Z) and the amount of methanol (X) and catalyst (Y) was obtained as follows:

\section{$\mathrm{Z}=31.083+8.109 \mathrm{X}+25.657 \mathrm{Y}-0.369 \mathrm{X}^{2}-5.070 \mathrm{Y}^{2}-0.639 \mathrm{XY}$}

$\mathrm{X}$ : Molar ratio of methanol to oil

Y: Mass ratio of sulfuric acid to oil (\%)

$\mathrm{Z}$ : Conversion of FFAs (\%)

Maximum conversion was $93.8 \%$ at $\mathrm{X}=9.31$ and $\mathrm{Y}=1.95$ (Fig. 2). When the molar ratio of methanol to oil was $9.31: 1$ and sulfuric acid was $1.95 \mathrm{wt} \%$ of oil, the expected final acid value was 6.38 $\mathrm{mg} \mathrm{KOH} / \mathrm{g}$. In the same condition, the acid value of trap grease became $7.6 \mathrm{mg} \mathrm{KOH} / \mathrm{g}$.

In the central composite design for the second esterification using trap grease of $7.6 \mathrm{mg} \mathrm{KOH} / \mathrm{g}$ acid value (Table 3 ), the relation between conversion $(\mathrm{Z})$ and the amount of methanol $(\mathrm{X})$ and catalyst (Y) was obtained, as follows:

\section{$\mathrm{Z}=53.011+2.806 \mathrm{X}-8.525 \mathrm{Y}-0.071 \mathrm{X}^{2}+2.934 \mathrm{Y}^{2}+0.025 \mathrm{XY}$}

X: Molar ratio of methanol to oil

Y: Mass ratio of sulfuric acid to oil (\%)

$\mathrm{Z}$ : Conversion of FFAs (\%)

However, the optimum condition did not exist (Fig. 3). When the molar ratio of methanol to oil increased, the conversion of FFAs also increased. The condition in which acid value was decreased to less than $3.0 \mathrm{mg} \mathrm{KOH} / \mathrm{g}$ was determined as the proper condition for trap grease with high FFA content. The molar ratio of methanol

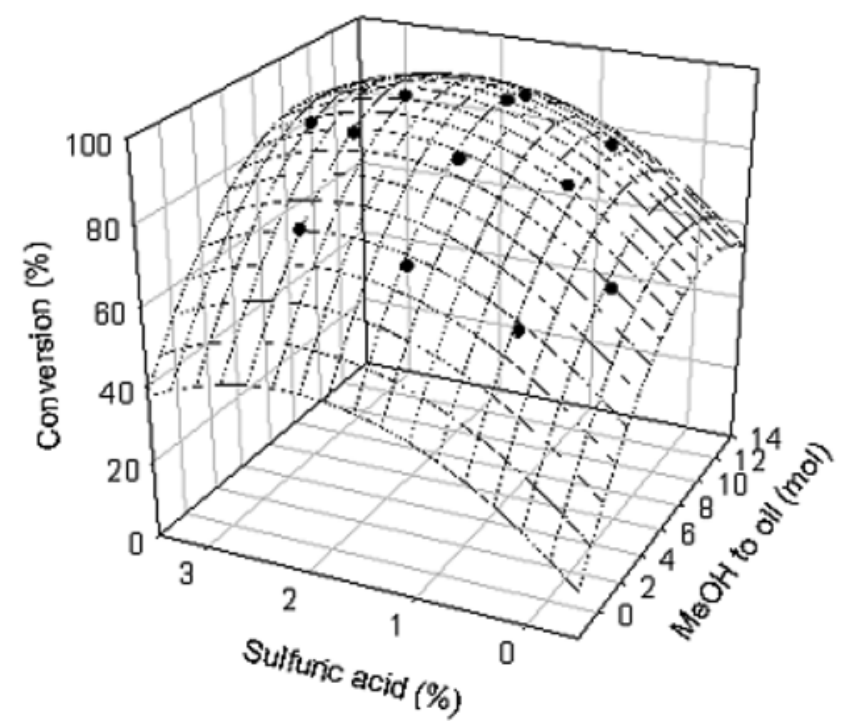

Fig. 2. Profile of the conversion in the first esterification of trap grease by sulfuric acid $\left(95^{\circ} \mathrm{C}\right.$ and $\left.1 \mathrm{~h}\right)$.
Table 3. Experimental matrix of the central composite design for the second esterification by sulfuric acid

\begin{tabular}{rccccc}
\hline \hline Run & $\mathrm{x}$ & $\mathrm{y}$ & $\begin{array}{c}\text { MeOH to oil } \\
(\mathrm{X}, \text { molar } \\
\text { equivalents })\end{array}$ & $\begin{array}{c}\text { Sulfuric } \\
\text { acid to oil } \\
(\mathrm{Y}, \mathrm{wt} \%)\end{array}$ & $\begin{array}{c}\text { Conversion } \\
\text { of FFAs } \\
(\mathrm{Z}, \%)\end{array}$ \\
\hline 1 & -1 & -1 & 2 & 0.5 & 55.00 \\
2 & -1 & 0 & 2 & 1.5 & 48.82 \\
3 & -1 & 1 & 2 & 2.5 & 51.05 \\
4 & 0 & -1 & 6 & 0.5 & 62.50 \\
5 & 0 & 1 & 6 & 2.5 & 70.00 \\
6 & 1 & -1 & 10 & 0.5 & 71.58 \\
7 & 1 & 0 & 10 & 1.5 & 66.32 \\
8 & 1 & 1 & 10 & 2.5 & 68.03 \\
9 & -1.414 & 0 & 0.344 & 1.5 & 51.97 \\
10 & -1.414 & 0 & 11.666 & 1.5 & 72.24 \\
11 & 0 & -1.414 & 6 & 0.1 & 66.32 \\
12 & 0 & 1.414 & 6 & 2.9 & 69.34 \\
13 & 0 & 0 & 6 & 1.5 & 60.26 \\
14 & 0 & 0 & 6 & 1.5 & 71.18 \\
15 & 0 & 0 & 6 & 1.5 & 63.03 \\
\hline $\mathrm{X}$
\end{tabular}

$\mathrm{X}=4 \mathrm{x}+6 ; \mathrm{Y}=\mathrm{y}+1.5$

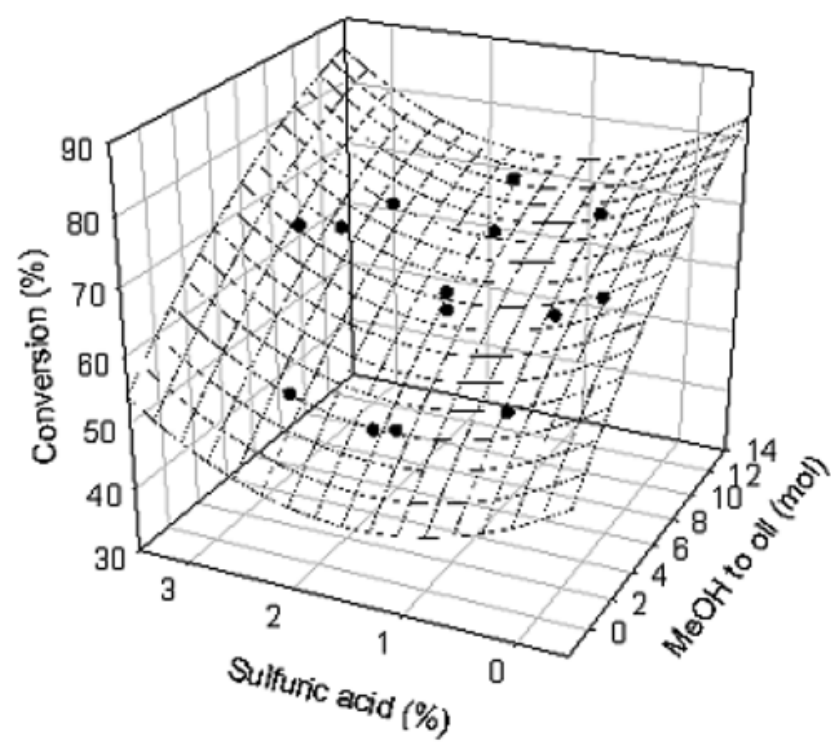

Fig. 3. Profile of the conversion in the second esterification of trap grease by sulfuric acid $\left(95^{\circ} \mathrm{C}\right.$ and $\left.1 \mathrm{~h}\right)$.

to oil was selected as $9: 1$. At the molar ratio of $9: 1$, the relation between conversion $(\mathrm{Z})$ and the amount of catalyst $(\mathrm{Y})$ was obtained, as follows:

$$
\begin{aligned}
& \mathrm{Z}=72.514-8.3 \mathrm{Y}-2.934 \mathrm{Y}^{2} \\
& \mathrm{Y} \text { : Mass ratio of sulfuric acid to oil }(\%) \\
& \mathrm{Z} \text { : Conversion of FFAs }(\%)
\end{aligned}
$$

Minimum conversion at the molar ratio of $9: 1$ was $66.6 \%$ at $\mathrm{Y}=1.414$. When the mass ratio of sulfuric acid to oil was less than or more than 1.414 , the conversion of FFAs increased. To minimize 
the amount of sulfuric acid, sulfuric acid was selected to $0.5 \mathrm{wt} \%$ of oil. The final acid value was expected to be $2.35 \mathrm{mg} \mathrm{KOH} / \mathrm{g}$. In the same condition, the acid value of trap grease became $2.75 \mathrm{mg}$ $\mathrm{KOH} / \mathrm{g}$. A two-step esterification reaction reduced the amount of sulfuric acid and the reaction time.

Trap grease with $2.75 \mathrm{mg} \mathrm{KOH} / \mathrm{g}$ acid value was transesterified using potassium hydroxide (Fig. 4). The molar ratio of methanol to oil was varied, at $3: 1,6: 1$, and $9: 1$. Potassium hydroxide was varied with $0.4,0.8$, and $1.2 \mathrm{wt} \%$ of oil. When the molar ratio of methanol to oil was $6: 1$ and potassium hydroxide was $0.8 \mathrm{wt} \%$ of oil, FAME content reached $92.4 \%$.

2. Esterification by Amberlyst-15 and Transesterification by Potassium Hydroxide

Instead of using sulfuric acid, which is toxic, Amberlyst-15 was

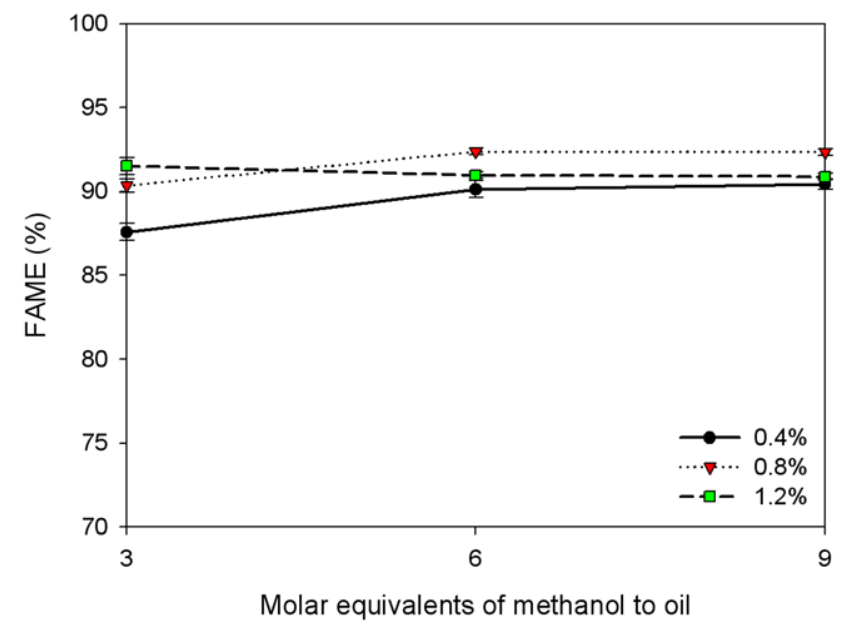

Fig. 4. Profile of FAME content with amount of methanol and KOH $\left(80^{\circ} \mathrm{C}\right.$ and $\left.0.5 \mathrm{~h}\right)$.

Table 4. Experimental matrix of the central composite design for the esterification by Amberlyst-15

\begin{tabular}{rccccc}
\hline \hline Run & $\mathrm{x}$ & $\mathrm{y}$ & $\begin{array}{c}\text { MeOH to oil } \\
\text { (X, molar } \\
\text { equivalents) }\end{array}$ & $\begin{array}{c}\text { Amberlyst- } \\
15 \text { to oil } \\
(\mathrm{Y}, \mathrm{wt} \%)\end{array}$ & $\begin{array}{c}\text { Conversion } \\
\text { of FFAs } \\
(\mathrm{Z}, \%)\end{array}$ \\
\hline 1 & -1 & -1 & 2 & 5 & 61.43 \\
2 & -1 & 0 & 2 & 15 & 71.96 \\
3 & -1 & 1 & 2 & 25 & 71.73 \\
4 & 0 & -1 & 6 & 5 & 77.01 \\
5 & 0 & 1 & 6 & 25 & 90.22 \\
6 & 1 & -1 & 10 & 5 & 74.37 \\
7 & 1 & 0 & 10 & 15 & 92.07 \\
8 & 1 & 1 & 10 & 25 & 90.46 \\
9 & -1.414 & 0 & 0.344 & 15 & 18.02 \\
10 & -1.414 & 0 & 11.666 & 15 & 91.93 \\
11 & 0 & -1.414 & 6 & 0.9 & 63.55 \\
12 & 0 & 1.414 & 6 & 29.1 & 93.72 \\
13 & 0 & 0 & 6 & 15 & 93.17 \\
14 & 0 & 0 & 6 & 15 & 93.35 \\
15 & 0 & 0 & 6 & 15 & 92.35 \\
\hline
\end{tabular}

$\mathrm{X}=4 \mathrm{x}+6 ; \mathrm{Y}=10 \mathrm{y}+15$

November, 2010 tested. In the central composite design for the esterification (Table 4), the relation between conversion $(\mathrm{Z})$ and the amount of methanol $(\mathrm{X})$ and catalyst (Y) was obtained, as follows:

$\mathrm{Z}=31.788+8.448 \mathrm{X}+2.897 \mathrm{Y}-0.550 \mathrm{X}^{2}-0.076 \mathrm{Y}^{2}+0.036 \mathrm{XY}$

$\mathrm{X}$ : Molar ratio of methanol to oil

Y: Mass ratio of Amberlyst-15 to oil (\%)

$\mathrm{Z}$ : Conversion of FFAs (\%)

Maximum conversion was $97.6 \%$ at $\mathrm{X}=8.37$ and $\mathrm{Y}=21.04$ (Fig. 5). When the molar ratio of methanol to oil was $8.37: 1$ and Amberlyst15 was $21.04 \mathrm{wt} \%$ of oil, the final acid value was expected to be $2.45 \mathrm{mg} \mathrm{KOH} / \mathrm{g}$. In the same condition, the acid value of trap grease became $3.23 \mathrm{mg} \mathrm{KOH} / \mathrm{g}$. The acid value decreased to near $3.0 \mathrm{mg}$ $\mathrm{KOH} / \mathrm{g}$ following esterification by Amberlyst-15, similar to the esterification with sulfuric acid. Because Amberlyst-15, as a heterogeneous catalyst, can be recovered and be reused, it is suitable to facilitate

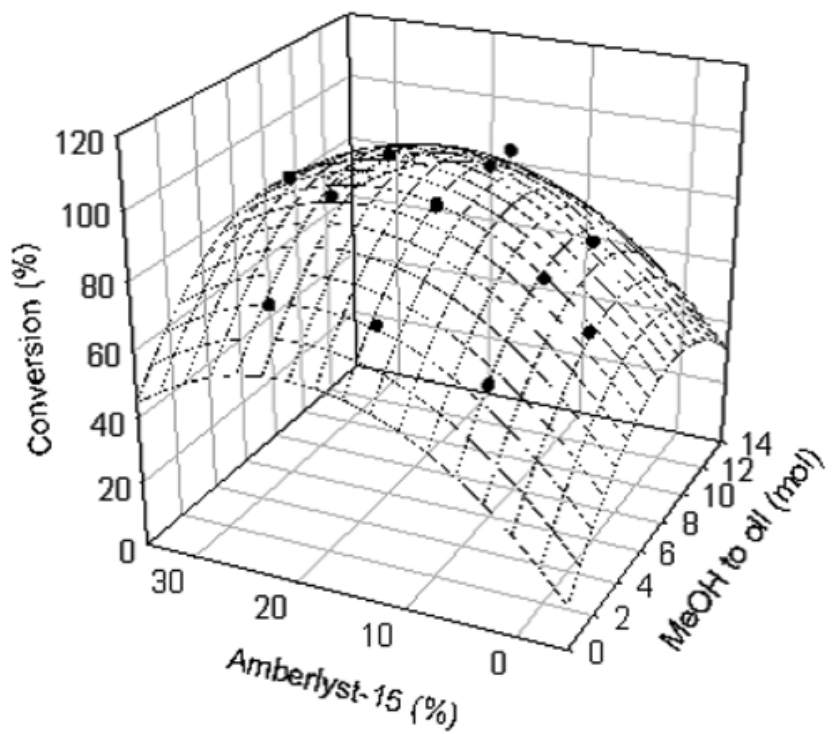

Fig. 5. Profile of the conversion in the esterification of trap grease by Amberlyst-15 (95 ${ }^{\circ} \mathrm{C}$ and $\left.3 \mathrm{~h}\right)$.

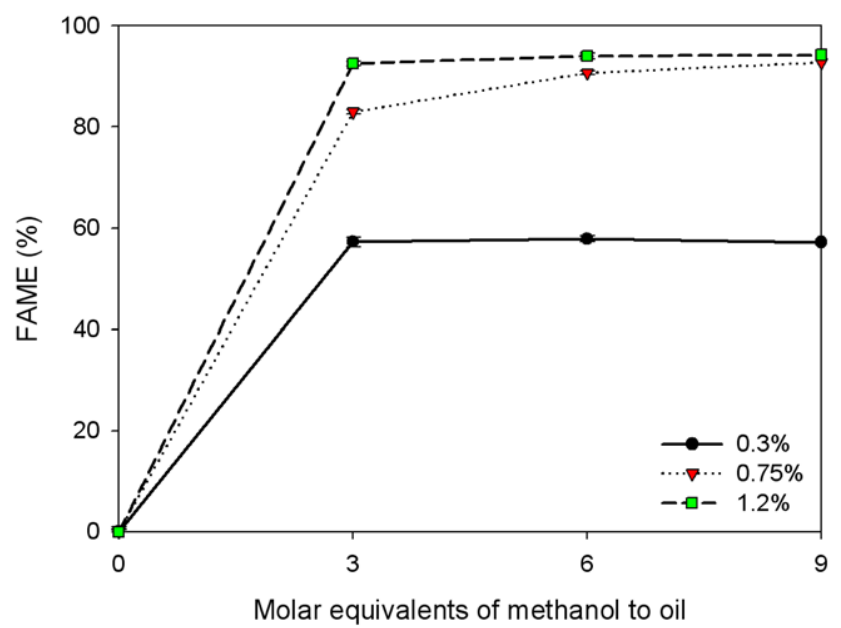

Fig. 6. Profile of FAME content with amount of methanol and $\mathrm{KOH}$ $\left(80^{\circ} \mathrm{C}\right.$ and $\left.0.5 \mathrm{~h}\right)$. 
Table 5. Properties of trap grease biodiesel

\begin{tabular}{lcc}
\hline \hline Properties & $\begin{array}{c}\text { Distillated } \\
\text { biodiesel }\end{array}$ & $\begin{array}{c}\text { BD } \\
\text { standard }\end{array}$ \\
\hline FAME (wt\%) & 97.6 & 96.5 \\
Acid value $(\mathrm{mg} \mathrm{KOH} / \mathrm{g})$ & 0.40 & 0.5 \\
Water content $(\mathrm{wt} \%)$ & 0.01 & 0.05 \\
Oxidation stability at $110{ }^{\circ} \mathrm{C}(\mathrm{h})$ & 0.17 & 6.0 \\
Total glycerin $(\mathrm{wt} \%)$ & 0.012 & 0.24 \\
CFPP $\left({ }^{\circ} \mathrm{C}\right)$ & 4 & 0 (Winter) \\
\hline
\end{tabular}

the continuous reaction for biodiesel production.

Trap grease with $3.23 \mathrm{mg} \mathrm{KOH} / \mathrm{g}$ acid value was transesterified using potassium hydroxide (Fig. 6). The molar ratio of methanol to oil was varied, at $3: 1,6: 1$, and $9: 1$. Potassium hydroxide levels were varied, at $0.3,0.75$, and $1.2 \mathrm{wt} \%$. When the molar ratio of methanol to oil was 6:1 and potassium hydroxide was $1.2 \mathrm{wt} \%$ of oil, FAME content reached $94.1 \%$.

\section{Properties of Trap Grease Biodiesel}

Table 5 shows the properties of trap grease biodiesel after distillation. After distillation, FAME content increased to $97.6 \%$. The total glycerin of trap grease biodiesel was very low. Oxidation stability was also very low, at $0.17 \mathrm{~h}$, as determined by the Rancimat method. Initial acid value was $102.9 \mathrm{mg} \mathrm{KOH} / \mathrm{g}$, but the acid value of trap grease biodiesel was $0.40 \mathrm{mg} \mathrm{KOH} / \mathrm{g}$. The CFPP of trap grease biodiesel was $4{ }^{\circ} \mathrm{C}$. As the oxidation stability and the CFPP did not satisfy the Korean Biodiesel Standard, additives were required for the improvement of oxidation stability and low temperature properties.

\section{CONCLUSIONS}

With its high FFA content, trap grease is a chemically challenging feedstock for biodiesel production. In this study, biodiesel was produced from trap grease through a process that involved esterification by an acid catalyst and then transesterification by an alkali catalyst. Although trap grease has very high FFA content, the process involving acid and alkali reactions showed higher FAME conversion than the unique acid process. In addition, Amberlyst- 15 was more desirable as a catalyst than sulfuric acid because of its potential for reuse and its environmental friendliness. The esterification of trap grease was optimized through response surface methodology, and a quadratic polynomial equation was obtained for conversion of FFAs. The optimum condition of esterification by Amberlyst15 was $8.37: 1$ at the molar ratio of methanol to oil and $21.04 \mathrm{wt} \%$ catalyst of oil. After the transesterification of $6: 1$ at the molar ratio of methanol to oil and $1.2 \mathrm{wt} \%$ potassium hydroxide of oil, FAME content was $94.1 \%$. After distillation, FAME content reached $97.6 \%$. Following the properties improvement of the trap grease biodiesel using additives, the trap grease biodiesel produced through this method was deemed suitable for use as a blend component of an alternative engine fuel.

\section{ACKNOWLEDGEMENTS}

This work took place under the cooperative project between KIER and GIEC, and was supported by Korea New and Renewable Energy Center (KNREC) and Korean Ministry of Commerce, Industry and Energy (KMOCIE).

\section{REFERENCES}

1. J. M. Marchetti, V. U. Miguel and A. F. Errazu, Renew. Sust. Energy Rev., 11(6), 1300 (2007).

2. M. J. Hass, S. Bloomer and K. Scott, J. Am. Oil Chem. Soc., 77(4), 373 (2000).

3. S. V. Ghadge and H. Raheman, Bioresource Technol., 97, 379 (2006).

4. N. Foidl, G. Foidl, M. Sanchez, M. Mittebach and S. Hackel, Bioresource Technol., 58, 77 (1996).

5. L. Canoira, R. Alcantara, M. J. G. Martinez and J. Carrasco, Biomass Bioenerg., 30, 76 (2006).

6. M. M. Conceicao, R. A. Candeia, F. C. Silva, A. F. Bezerra, V. J. Fernandes and A. G Souza, Renew. Sust. Energy Rev., 11, 964 (2007).

7. Z. M. Wang, J. S. Lee, J. Y. Park, C. Z. Wu and Z. H. Yuan, Korean J. Chem. Eng., 24(6), 1027 (2007).

8. B. Freedman, E. H. Pryde and T. L. Mounts, JAOCS, 61, 1638 (1984).

9. Y. Zhang, M. A. Dube, D. D. Mclean and M. Kates, Bioresource Technol., 89, 1 (2003).

10. Z. M. Wang, J. S. Lee, J. Y. Park, C. Z. Wu and Z. H. Yuan, Korean J. Chem. Eng., 25(4), 670 (2008).

11. Y. Liu, E. Lotero and J. G. Goodwin, J. Catal., 243, 221 (2006).

12. O. Iglesia, R. Mallada, M. Menendez and J. Coronas, Chem. Eng. J., 131, 35 (2007).

13. J. Lilja, D. Y. Murzin, T. Salmi, J. Aumo, P. Maki-Arvela and M. Sundell, J. Mol. Catal. A: Chem., 182-183, 555 (2002).

14. X. Hou, Y. Qi, X. Qiao, G. Wang, Z. Qin and J. Wang, Korean J. Chem. Eng., 24(2), 311 (2007).

15. J. Y. Park, D. K. Kim, S. A. Kim, J. D. Choi and J. S. Lee, KIChE Spring Meeting, P-5, 190 (2009).

16. F. Collignon, R. Loenders, J. A. Marens, P. A. Jacobs and G. Poncelet, J. Catal., 182, 302 (1999).

17. J. M. Marchetti, V. U. Miguel and A. F. Errazu, Fuel, 86, 906 (2007).

18. D. E. Lopez, J. G. Goodwin, D. A. Bruce and E. Lotero, Appl. Catal. A: Gen., 295, 97 (2005).

19. T. Wan, P. Yu, S. Gong, Q. Li and Y. Luo, Korean J. Chem. Eng., 25(5), 998 (2008).

20. J. Y. Park, Z. M. Wang, D. K. Kim and J. S. Lee, Renew. Energy, 35, 614 (2010). 